\title{
A musculus tibialis anterior ín fedett szakadása
}

\author{
Esettanulmány
}

\author{
DR. TÁTRAI MIKLÓS, DR. HALASI TAMÁS
}

\section{ÖSSZEFOGLALÁS}

A musculus tibialis anterior ín fedett szakadása viszonylag ritka kórkép. A szakirodalomban csekély számú közleményt olvashatunk, amelyek legtöbbször esettanulmányok. A szerzők a saját praxisuk során diagnosztizált musculus tibialis anterior ín szakadásának ellátását ismertetik. A 73 éves férfi beteg bokája teniszezés közben fájdult meg, direkt trauma nem érte. Bokája-lába megduzzadt, lábát extendálni nem tudta, izomereje jelentősen gyengült, járása nehezítetté vált. Fizikális vizsgálattal enyhe nyomásérzékenység mellett a musculus tibialis anterior ina nem volt tapintható. Ultrahangvizsgálat a szakadást megerősítette. A sérüléstől számítva 4 hét múlva végeztük az ín rekonstrukcióját, amely során medialis metszésből az inat felöltve, azt az os medialis cuneiforméba fúrt lukon keresztül reinzertáltuk, majd a fonalakat az ellenoldali corticalis felett megcsomóztuk. A végtagot négy hétig rögzítettük, majd aktív tornát kezdtünk. Öt hónappal a mútétet követően az izomerő helyreállt, a beteg sántítás nélkül képes járni. AOFAS score 83 , amely jó funkciót jelent. A beteg a mútét eredményével elégedett, újra teniszezik.

\section{Kulcsszavak: Ínsérülés; Ínszakadás; Lábsérülés; Rekonstrukciós mütét;}

\section{Tátrai, T. Halasi: Closed rupture of the tibialis anterior tendon is a relatively rare injury}

The number of publications in the topic is very low and a major part of them consists mainly of case studies. The authors typically describe the treatment of tibialis anterior tendon ruptures diagnosed in their patients. A 73-year-old male while playing tennis experienced pain in his ankle although there had been no direct trauma. The ankle was swollen, he could not extend his leg, his muscle strength decreased, and he had difficulty walking. On physical examination the patient experienced mild pressure sensitivity and the tibialis anterior tendon could not be palpated. The ultrasound confirmed the rupture. The tendon repair surgery was performed four weeks after the injury. During the operation through a medial incision we reinserted the tendon through a drill-hole into the medial cuneiform bone and the threads were knotted above the contralateral cortical bone. The extremity was immobilized for four weeks, which was followed by active rehabilitation. Five months after the surgery the muscle strength was restored, the patient walks without limping. The AOFAS score is 83 , which is an indicative of good function. The patient is satisfied with the result of the surgery, he can play tennis again.

Key words: $\quad$ Leg injuries - Surgery/Therapy; Rupture;

Reconstructive surgical procedures; Tendon injuries - Surgery/Therapy; 


\section{BEVEZETÉS}

A musculus tibialis anterior ín fedett szakadása ritka, föleg idős korban következik be. Férfiaknál csaknem másfélszer gyakoribb. A különböző cikkek 58-72 év közötti átlagéletkort adnak meg. Általában spontán, vagy minor traumára következik be a szakadás, ritkábban adekvát traumára (11), illetve írtak le csontos abruptiót is (10). Több szerző a láb extenziós, everziós sérüléseként írja le (8). $\mathrm{Az}$ I. tarso-metatarsalis ízületbe adott lokális szteroid injekciók szerepet játszhatnak az ín spontán szakadásban (7). A diagnózis a fizikális vizsgálattal valószínűsíthető, az UH dinamikus vizsgálatot tesz lehetővé, ezáltal fontos része a kivizsgálásnak, bizonytalanság esetén MR vizsgálat szóba jön. A szakadás az ín különböző magasságában következhet be. Írtak le izom-ín átmenetben történt szakadást (9), lehetséges tapadáshoz közeli szakaszon, vagy leszakadhat az os cuneiforméról. Extrém esetként publikáltak 25 éves sérülést, amely során a musculus extensor hallucis longus és a musculus extensor digitorum longus kompenzatórikus hypertrophiáját találták, az ujjak kalapács deformitásával, metatarsalgiával, neuromákkal (3). Idősebb betegeknél a konzervatív kezelést részesítik előnyben, míg fiatalabb korban a mútéti ellátást javasolják. Christman-Skieller (2) és munkatársai összegezték a szakirodalomban található mútéti típusokat. Leggyakoribban primer ínvarratot végeztek, ezt követi az anatómiai reinsertio és autograft használata. Ez utóbbi történhetett $m$. extensor digitorum longus, Achilles ín, hamstring ín (5), illetve m. plantaris ín felhasználásával. Ritkábban alkalmazott technikaként leírták a m. tibialis anterior ín hosszabítását, allograft használatát, extensor hallucis longus transfert, az os naviculareba vagy a talus nyakába történő nem anatómiai reinsertiót. Három hónappal a sérülést követően anatómiai reinsertiót eddig nem publikáltak a következményes ín retrakció miatt.

$\mathrm{Az}$ eredmények mérése több pontrendszer szerint lehetséges. A leggyakoribbak az MMS, FAOS, AOFAS (6), FAAM (1). A mútétet követően technikától függetlenül jó eredményt publikáltak. Tekintettel az igen kis esetszámra, kontrollcsoport bevonásával készült prospektív tanulmány nem áll rendelkezésünkre, ugyanakkor a FAOS scoreban jelentősen jobb eredmények születtek az operált betegeknél a konzervatív kezeléssel szemben $(84.4-69,4)$.

\section{ESETISMERTETÉS}

73 éves férfi beteg a sérülés után két héttel jelentkezett ambulanciánkon, teniszezést követő bokafájdalom miatt. Fizikális vizsgálattal a boka felett ventralisan duzzanat volt látható. A láb extenziója nem volt kivitelezhető, az izomerő jelentősen gyengült, emiatt a beteg sántított. Palpatióval a tapadásnak megfelelően enyhe nyomásérzékenység volt jelen, valamint a $\mathrm{m}$. tibialis anterior ina extenzió során nem volt tapintható (1. ábra). Képalkotó eljárás során először kétirányú röntgenfelvétel készült a csontos abruptio kizárása céljából. Ezt követően UH vizsgálatot végeztünk, amely kimutatta az ín folytonosság hiányát, valamint a szakadt íncsonkot. Ennek ismeretében nem tartottuk szükségesnek az MR felvétel elvégzését. Prepoeratív AOFAS score-ja a betegnek 63 volt. Négyhetes korban végeztük el a mútétet, amely során medialis feltárásból felkerestük a szakadt inat, majd a szakadásnál a végét felfrissítettük, 2 db felszívódó fonállal keresztezett öltésekkel az inat felöltöttük. A medialis cuneiformén dorsalisan $8 \mathrm{~mm}$-es furatzsákot készítettünk, amelynek alapjára $2 \mathrm{db}$ 4,5 mm-es furatot fúrtunk a fonalaknak. Ezt követően az inat behúztuk és a lábat extendálva az ellenoldali kortikálison megcsomóztuk őket (2. ábra). Réteges sebzárás után varratszedésig fekvő gipszsínt, majd további három hétig járógipszet helyeztünk fel. Gipszlevételt követően a beteg gyógytornán vett részt heti két alkalommal. Öt hónappal a mútétet követően a beteg sántítás nélkül képes járni, az izomerő helyreállt. A boka passzív mozgásterjedelme teljes volt, ugyanakkor az aktív extenzió és supinatio 10 fokot elmaradt (3-4. ábra). Az extenziós elmaradást a $\mathrm{m}$. extnesor hallucis longus, valamint a $\mathrm{m}$. extensor digitorum izmokkal próbálja kompenzálni, ezek inai a bőrt előemelik. A beteg az eredménnyel elégedett, ismét teniszezik. AOFAS score-ja 83 lett. 


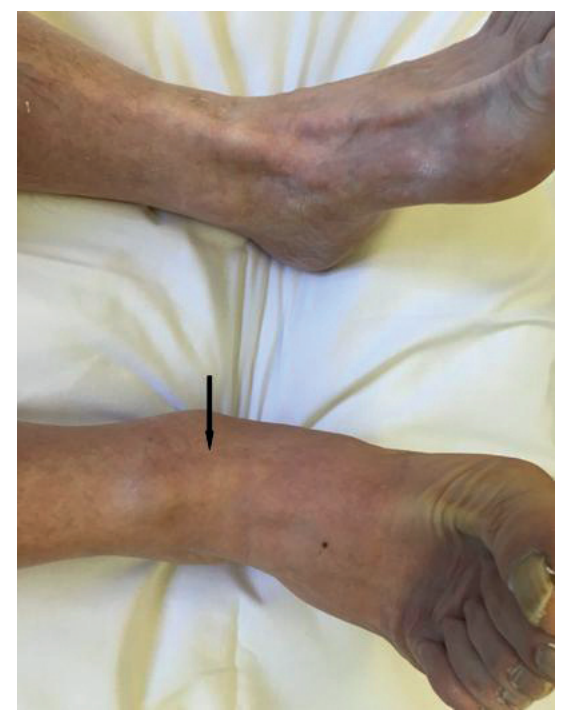

1. ábra Extenzió mellett látható (fekete nyil) a m. tibialis anterior ín hiánya

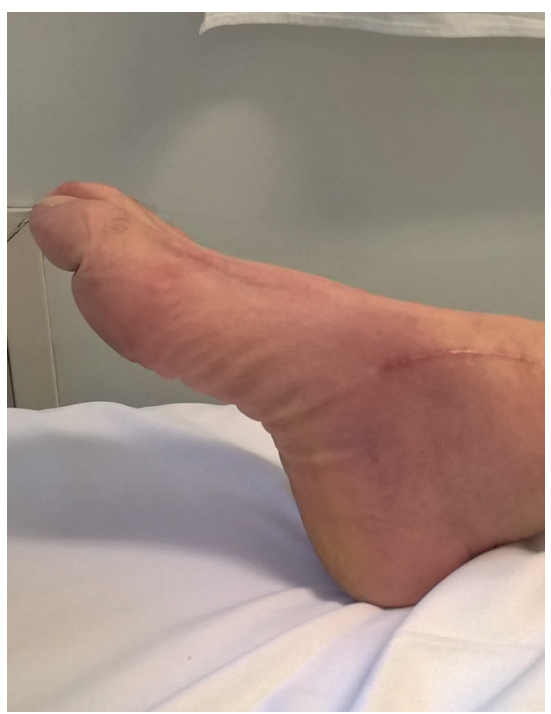

3. ábra Plantar flexio teljes

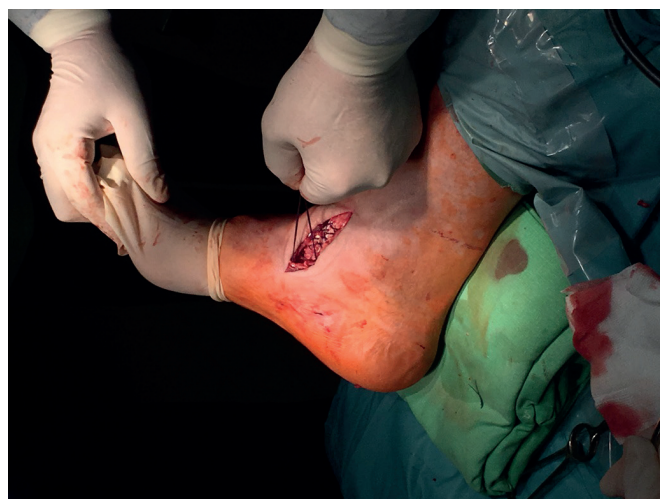

2. ábra Az ín reinsertiója, és a fonalak csomózása extendált boka mellett

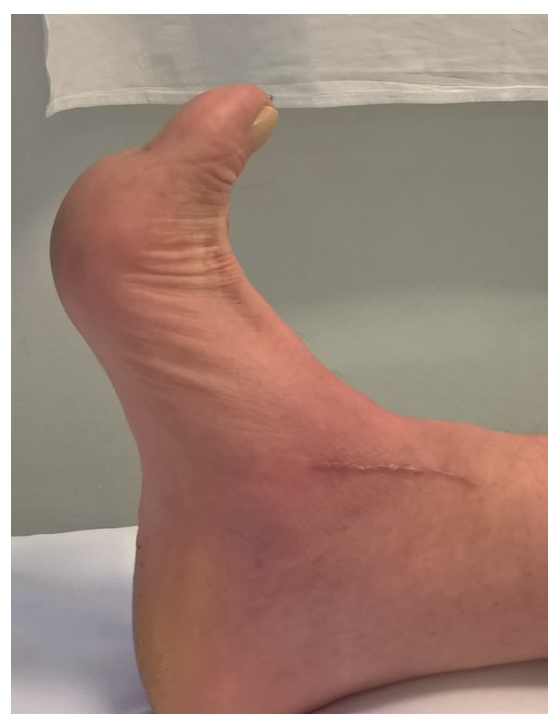

4. ábra 10 fokos extenziós elmaradás, a m. extensor hallucis longus ina a bört elöemeli 


\section{MEGBESZÉLÉS}

A m. tibialis anterior ín fedett szakadása, főleg idősebb korú férfiaknál jelentkező relatív ritka kórkép. Az irodalomban csekély esetszámú közlemény található. A kezelés alapvetően mútéti ellátás (11), ám idős, rossz általános állapotú betegnél lehetséges konzervatív kezelés is, bár ennek eredményei szerényebbek a mútéti rekonstrukciókhoz képest. Christman-Skieller és munkatársai összegezték a különböző kezelési lehetőségeket (2). Az első választandó ellátás, ha kivitelezhető, a direkt ín varrat. Amennyiben a csonk túl rövid, és a varrat nem megoldható, úgy az anatómiai reinzerciót javasolják (10). Inveterált esetben, a csonk retrahálódik, így az anatómiai reinzerció nem kivitelezhető. Ebben az esetben autoallograft beültetése, íntranszfer, vagy nem anatómiai reinzerció a választható ellátás. Esetünkben a 73 éves férfi betegnél végeztük el az ín reinzercióját a sérüléstől számított 4 . héten. A tibialis anterior anatómialiag az I. metatarsus, valamint a medialis cuneiformén plantarisan tapad, ugyanakkor mi a reinzerciót csak dorsal felől tudtuk elvégezni. Vélhetően ez magyarázhatja az extenzióban, illetve supinatióban jelentkező elmaradást. Amennyiben a mútétet akutan tudtuk volna elvégezni, elképzelhető, hogy az ín kevésbé retrahálódott volna, így az anatómiai reinzerció kivitelezhető lett volna. Ennek ellenére a mútétet sikeresnek értékeljük, mert az aktív mozgáselmaradás a beteget nem zavarja, az izomereje helyreállt, és a sérülés előtti szinten képes volt ismét sportolni. AOFAS score-ja 63-ről 83-ra javult, amely az irodalmi adatokkal megegyező értéket mutat (4).

\section{IRODALOM}

1. Burton A., Aydogan U.: Repair of chronic tibialis anterior tendon rupture with a major defect using gracilis allograft. Foot Ankle Spec. 2016. 9 (4): 345-350. https://doi.org/10.1177/1938640015624757

2. Christman-Skieller C., Merz M. K., Tansey J. P.: A systematic review of tibialis anterior tendon rupture treatments and outcomes. Am. J. Orthop. 2015. 44. (4): 94-99.

3. Cohen D A., Gordon D. H.: The long-term effects of an untreated tibialis anterior tendon rupture. J. Am. Podiatr. Med. Assoc. 1999. 89. (3): 149-152. https://doi.org/10.7547/87507315-89-3-149

4. Funk S. S., Gallagher B., Thomson A. B.: Repair of chronic tibialis anterior tendon ruptures. Orthopedics, 2016. 39. (2): 386390. https://doi.org/10.3928/01477447-20160307-05

5. Goehring M., Liakos P.: Long-term outcomes following anterior tibialis tendon reconstruction with hamstring autograft in a series of 3 cases. J. Foot Ankle Surg. 2009. 48. (2): 196-202. https://doi.org/10.1053/i.jfas.2008.12.001

6. Haijun M., Guanyue X.: Soft tissue repair for tibialis anterior tendon ruptures using plate and screw fixation technique in combination with anterolateral thigh flaps transplantation. J. Orthop. Surg. Res. 2015. $10: 143$. https://doi.org/10.1186/s13018-015-0278-5

7. Jain K., Asad M., Joshi Y., Syed A.: Tibialis anterior tendon rupture as a complication of first tarsometatarsal joint steroid injection: A case report and review of literature. Foot (Edinb). 2015. 25. (3): 179-181.

8. Jerome J. T., Varghese M., Sankaran B., Thomas S. K.: Tibialis anterior tendon rupture in gout -- case report and literature review. Foot Ankle Surg. 2008. 14. (3): 166-169. https://doi.org/10.1016/i.foot.2015.05.008

9. Kotha K. M. R., Tandra V. S., Murthy G. V. S., Vutukuri S. R., Vyjayanthi Y.: Tibialis anterior partial rupture mimicking muscle hernia: A rare case report. Clin. Diagn. Res. 2014. 8. (10): LD08-LD09.

10. Rajeev A., McDonald M., Newby M., Patterson P.: Traumatic avulsion of tibialis anterior following an industrial accident: $A$ case report. Int. J. Surg. Case Rep. 2015. 14: 125-128. https://doi.org/10.1016/j.ijscr.2015.06.043

11. Zajonz D., Köhler L., Pretzsch M., Lingscheidt T., Moche M., Heyde C. E., Scholz R.: Operative Therapie der Tibialis-anteriorSehnenruptur. Orthopäde, 2015. 44 (4): 303-313. https://doi.org/10.1007/s00132-015-3090-3

\section{Dr. Tátrai Miklós}

Országos Sportegészségügyi Intézet, Sportsebészeti Osztály

1113 Budapest, Karolina út 27.

miklos.tatrai@gmail.com 